\title{
Narządy krytyczne oraz ocena wczesnych i późnych powikłań po napromienianiu całego ciała
}

\section{Critical organs and evaluation of early and late complications after Total Body Irradiation}

\author{
Dominika Wójcik ${ }^{1,}$ \\ ${ }^{1}$ Uniwersytet Medyczny im. Karola Marcinkowskiego w Poznaniu
}

\section{Streszczenie}

Efekt radioterapeutyczny w dużej części zależy od wielkości dawki zadanej w obszar tarczowy. Jednak ograniczeniem są narządy krytyczne, które znajdują się w pobliżu napromienianej zmiany. Przekroczenie dawek tolerancji w tych narządach może być przyczyną powstania szeregu powikłań popromiennych. U chorych z rozrostowymi nowotworami krwiotwórczymi, u których zaleca się przeprowadzenie przeszczepu szpiku kostnego, wykonuje się leczenie przygotowawcze w postaci napromienienia całego ciała techniką TBI (ang. Total Body Irradiation) połączonego z leczeniem chemioterapeutycznym. Przy wykonywaniu procedury TBI - obszarem otrzymującym dawkę terapeutyczną jest całe ciało chorego z wyjątkiem płuc osłoniętych przez indywidualnie dobrane aplikatory ze stopu Wood’a. Niezamierzonym skutkiem radioterapii są liczne zmiany popromienne, które ze względu na czas wystąpienia po leczeniu dzielimy na wczesne i późne. Należą do nich $\mathrm{m}$. in. Radiation pneumonitis, zmętnienie soczewki oka, zaczerwienienie skóry, zaburzenia produkcji hormonu wzrostu. Część zmian ma charakter odwracalny, natomiast niektóre mogą przybrać charakter stały, nieodwracalny.

\begin{abstract}
The radiotherapeutic effect generally depends on the amount of dose set in the target region. However, the critical organs which are located near the irradiated lesion are the limitation. Overdose in these organs can cause a lot of radiation complications. In patients with proliferative haematopoietic conditions, where bone marrow transplantation is recommended, the Total Body Irradiation Therapy (TBI) is used in combination with chemotherapeutic treatment. During the TBI procedure, the area receiving the therapeutic dose is the entire body of the patient, except of the lungs sheltered by individually selected Wood's alloy applicators. Unintended consequences of radiation therapy are many radiation induced changes, which are divided into early and late, according to when they occur after the treatment. These include radiation pneumonitis, ophthalmic opacity, skin flushing, growth hormone production disorders. Some of the changes are reversible, while others can be permanent, irreversible.
\end{abstract}


Słowa kluczowe: napromienianie całego ciała; narządy krytyczne; powikłania popromienne

Keywords: Total Body Irradiation; critical organs; radiation complications

\section{Wstęp}

Przeszczep komórek macierzystych poprzedzony kondycjonowaniem radio - chemioterapeutycznym stanowi istotny etap leczenia $\mathrm{u}$ chorych $\mathrm{z}$ zaawansowanymi nowotworami układu krążenia. Pierwszy przeszczep szpiku kostnego poprzedzony napromienianiem całego ciała został przeprowadzony w 1957 r. przez Thomasa z USA i Georges Mathe z Francji u chorych z wysoce zaawansowanymi białaczkami. Terapia była oparta na badaniach z czasów II wojny światowej, w których dowiedziono niszczycielskie działanie promieniowania na szpik kostny. Leczenie z zastosowaniem techniki TBI dedykowane jest przede wszystkim osobom z ostrą postacią białaczki szpikowej oraz postacią ostrej białaczki limfoblastycznej. Taki sposób leczenia cechuje jednak duża toksyczność. Narządy, które w wyniku napromieniania znajdują się w polu wiązki pochłaniają pewną dawkę terapeutyczną. Może to skutkować powstaniem szeregu powikłań. Najpoważniejszym efektem radioterapii jest wyidukowany wtórny nowotwór. Aby niekorzystnych następstw terapii było coraz mniej, a wielkość dawki w obszarze zmienionym nowotworowo była taka sama lub większa przy jednoczesnym zabezpieczeniu narządów krytycznych, poszukuje się nowych technik napromieniania $[1-3]$.

\section{Cel pracy}

Celem pracy jest ocena wczesnych i późnych powikłań popromiennych u chorych ze złośliwymi zmianami rozrostowymi układu krwiotwórczego u których przeprowadzone zostało kondycjonowanie z wykorzystaniem radioterapii całego ciała techniką TBI przed przystąpieniem do przeszczepu komórek macierzystych.

\section{TBI - napromienienie całego ciała}

Technika TBI (ang. total body irradiation) należy do metod przygotowujących chorego do przeszczepu allogenicznych lub autologicznych komórek macierzystych BMT (ang. bone marrow transplanatation). Głównym zadaniem terapii jest podanie choremu dawki immunoablacyjnej i wywołanie immunosupresji. Podanie wysokiej dawki w obszar leczony ma za zadanie zabić komórki gospodarza, w tym komórki nowotworowe oraz ma na celu ochronić organizm biorcy przed odrzuceniem przeszczepu. Obszarem tarczowym jest szpik kostny. Celem radioterapii jest dostarczenie dawki w obszar leczony, przy jednoczesnej ochronie narządów krytycznych. Podczas napromieniania dawką terapeutyczną objęte zostaje całe ciało pacjenta. Początkowo, do lat 90 chory napromieniany był promieniowaniem gamma pochodzącym ze źródła kobaltowego. Aparaty gammaterapeutyczne zostały zastąpione przez nowocześniejsze akceleratory liniowe emitujące promieniowanie fotonowe oraz elektronowe. W zależności od wskazań klinicznych, dawka na ciało wynosi od 12 do 14,4 Gy. Najczęściej stosowany jest schemat 6 frakcji, 2 razy dziennie, rano i wieczorem, z optymalnym 6 godzinnym odstępem pomiędzy seansami terapeutycznymi. Dawka na płuca nie może przekroczyć 9 Gy - ze względu na wysoką promieniowrażliwość narządu. Standardowo stosowane są pola przednio - tyle (AP, ang. anterior - posterior), tylno - przednie (PA, ang. posterior - anterior), pola boczne (ang. lateral) oraz elektronowe. Pola elektronowe stosuje się, aby dopromienić ścianę klatki piersiowej, która przy napromienianiu promieniowaniem fotonowym zasłonięta jest przez indywidualnie dobrane osłony $[1,2]$.

\section{Dawki tolerancji w narządach krytycznych podczas napromieniania techniką TBI}

Przeprowadzenie procedury TBI przed przystąpieniem do przeszczepu komórek krwiotwórczych wiąże się z otrzymaniem przez organizm biorcy jednorodnej dawki promieniowania obejmującej całe ciało. Do narządów krytycznych znajdujących się w obszarze napromienianym należą m.in. serce, płuca, nerki, wątroba, skóra, soczewka oka, ślinianki oraz gonady męskie i żeńskie. Przed przystąpieniem do leczenia, 
ważne jest aby określić tzw. dawki tolerancji prawidłowych tkanek znajdujących się w okolicy leczonej. Dawka tolerancji jest to dawka pochłonięta, której przekroczenie związane jest z powstaniem dopuszczalnych powikłań radioterapii u chorych stanowiących mniej niż 5 \% leczonych w ciągu 5 lat od napromieniania (TD ${ }_{5 / 5}$. Przekroczenie dawki nie może wiązać się z przewyższeniem celowości leczenia. Wyjątek stanowi rdzen̆ kręgowy, którego uszkodzenie - skutkujące powstaniem martwicy nie może wystąpić u więcej niż 1 \% leczonych [2].

W tabeli poniżej zostały zestawione zalecenia wielkości dawek dla narządów krytycznych po radioterapii przy zastosowaniu jednej frakcji dziennie w dawce 2 Gy przez 5 dni w tygodniu.

Tabela 1. Dawki tolerancji dla narządów krytycznych, gdzie zastosowano schemat leczenia w postaci 2 Gy, raz dziennie przez 5 dni w tygodniu [1].

\begin{tabular}{|c|c|c|c|}
\hline Narząd krytyczny & $\begin{array}{c}\text { Dawka tolerancji } \\
\text { [Gy] TD 5/5- TD 5/50 }\end{array}$ & Narząd krytyczny & $\begin{array}{c}\text { Dawka tolerancji } \\
\text { [Gy] TD 5/5 - TD 5/50 }\end{array}$ \\
\hline Serce (jako cały organ) & $43-50$ & Mózg & $54-70$ \\
\hline Serce (jako część organu) & $55-65$ & Wątroba & $35-40$ \\
\hline Kości & $65-70$ & Soczewka & $6-12$ \\
\hline Pęcherz & $65-75$ & Limfocyty & 10 \\
\hline Jelito Grube & $65-75$ & Jądra & $6-10$ \\
\hline Śluzówka & $65-75$ & Jajnik & $15-20$ \\
\hline Przewód pokarmowy & $50-55$ & $\begin{array}{c}\text { Komórki macierzyste } \\
\text { Szpiku }\end{array}$ & $3-5$ \\
\hline $\begin{array}{c}\text { Nerka, kłębuszki } \\
\text { nerkowe }\end{array}$ & $23-28$ & $\begin{array}{c}\text { Zmieniony chorobowo szpik } \\
\text { kostny }\end{array}$ & $25-35$ \\
\hline Płuco & $20-30$ & Szpik kostny & $45-50$ \\
\hline Rdzeń kręgowy & $50-60$ & & \\
\hline
\end{tabular}

Ze względu na możliwość dłuższego okresu przeżycia oraz brak w pełni dojrzałych narządów, dzieci zupełnie inaczej niż dorośli reagują na radioterapię. Narządy młodych osób są bardziej narażone na popromienne działania niepożądane. Im wyższa dawka zadana i im większa objętość napromienia tym prawdopodobieństwo rozwoju powikłań w wieku dziecięcym jest większe. Dlatego też zaleca się, aby dawka u dzieci była nieco niższa niż u osób dorosłych. Według zaleceń, dawka frakcyjna u dzieci poniżej 3 roku życia powinna mieścić się w granicach 1,2 Gy - 1,5 Gy natomiast u dzieci powyżej 3 roku życia w przedziale 1,8 - 2 Gy. W tabeli poniżej zestawione zostały dawki tolerancji w wybranych narządach u dzieci $[2,4,5]$.

Tabela 2. Dawki frakcyjne oraz dawki tolerancji w wybranych narządach u dzieci [2].

\begin{tabular}{|c|c|c|}
\hline Narząd & Dawka tolerancji [Gy] & Dawka frakcyjna [Gy] \\
\hline Płuco (część) & $28-30$ & $1,5-2$ \\
\hline Płuco (całe) & $<20$ & $1,5-2$ \\
\hline Nerki (obie) & 12 & $1,5-1,8$ \\
\hline Nerki (jedna) & $15-20$ & $1,5-1,8$ \\
\hline
\end{tabular}




\begin{tabular}{|c|c|c|}
\hline Wątroba (cała) & 20 & $1,5-1,8$ \\
\hline Wątroba (część narządu) & 30 & $1,5-1,8$ \\
\hline Jajniki & $<5-6$ & $1,5-1,8$ \\
\hline Jądra & $<5$ & $1,5-1,8$ \\
\hline Podwzgórze & 30 & $1,5-1,8$ \\
\hline Przynasady (częściowe zamykanie \\
wzrostu) & 10 & $1,5-1,8$ \\
\hline Mózg (poniżej 2 roku życia) & 45 & 1,5 \\
\hline Mózg (powyżej 2 roku życia) & 55 & $1,5-2$ \\
\hline Soczewka & $5-10$ & \\
\hline
\end{tabular}

\section{Wczesne oraz późne powikłania popromienne}

Promieniowanie jonizujące działa nie tylko na komórki nowotworowe. Ma wpływ również na komórki prawidłowe, które leżąc w bezpośrednim sąsiedztwie zmiany nowotworowej oraz pochłaniając pewną dawkę promieniowania są przyczyną powstania niekorzystnych następstw ubocznych radioterapii. Ze względu na okres czasu w jakim mogą one wystąpić, stosuje się podział na powikłania wczesne oraz późne. Powikłania wczesne mogą pojawić się podczas trwania seansu radioterapeutycznego i często mają charakter odwracalny. Powikłania późne potrafią rozwinąć się dopiero po pewnym czasie (nawet po kilkunastu latach). Aktywacja wczesnych oraz późnych powikłań popromiennych zależy od trzech podstawowych czynników: rodzaju i wielkości dawki zadanej, warunków napromieniania oraz od cech biologicznych napromienianego narządu. Pomimo tego, że zmniejszyła się śmiertelność chorych po przeszczepie szpiku kostnego to odnotowuje się szereg, różnych, późnych następstw związanych z leczeniem radio - chemioterapeutycznym. W trakcie trwania zabiegu lub w przedziale od 12 do 24 godzin po, u prawie wszystkich chorych mogą wystąpić wczesne objawy niepożądane takie jak nudności, wymioty, biegunka. Zapalenie ślinianek średnio występuje u $40 \%$ chorych, a dreszcze i podwyższona temperatura ciała u $10 \%$. Zmiany skórne takie jak przebarwienia, rumień, łysienie, świąd oraz nadmierna suchość dotyczą wszystkich leczonych i najczęściej pojawiają się między 2, a 10 dniem po radioterapii. Także niski próg bólu należy do objawów mogących pojawić się w następstwie leczenia. Powikłania ze strony jamy ustnej związane są z zapaleniem śluzówek oraz suchością jamy ustnej. Doskwierają 90 \% leczonym i uaktywniają się miedzy 5, a 10 dniem po zakończonej terapii. Dodatkowo powikłania popromienne ze strony układu endokrynnego, zaburzeń metabolicznych węglowodanów i tłuszczy, zaburzenia wzrostu kości, hipogonadyzm, zaburzenia sercowo - naczyniowe oraz dotyczące komórek krwi, zaburzenia układu oddechowego, narządu wzroku, układu moczowego oraz ryzyka powstania wtórnych nowotworów zostały opisane kolejno poniżej $[1,2,9]$.

\section{Układ endokrynny}

Problemy związane z działaniem układu endokrynnego należą do częstych powikłań leczenia z wykorzystaniem wysokodawkowej radioterapii, chemioterapii oraz leków stosowanych w przebiegu choroby pierwotnej. Podstawowymi czynnikami wpływającymi na prace gruczołu jest stan fizyczny i wiek chorego. U dzieci i młodzieży najczęściej można się spotkać z zaburzeniami pracy tarczycy, zaburzeniami związanymi z poziomem hormonu wzrostu, z uszkodzeniem gonad, opóźnieniem dojrzewania płciowego oraz z zaburzeniami gospodarki węglowodanowej. Efektem niepożądanym radioterapii jest rozwój różnych podtypów niedoczynności, która mogą mieć postać subklinicznej niedoczynności tarczycy, jawnej pierwotnej niedoczynności tarczycy lub wtórnej niedoczynności tarczycy. Subkliniczna niedoczynność tarczycy jest łagodną, zwykle ustępującą postacią niewydolności gruczołu. Występuje u 7,5-15\% chorych. Wszystkie działania ze strony gruczołu wydzielania wewnętrznego mogą wynikać z wielohormonalnej niedoczynności 
przysadki mózgowej. Sanders i in. podjęli się 30 - letniej obserwacji chorych po przeszczepie komórek macierzystych. Zaobserwowali, że u 30 \% leczonych występują różnego rodzaju zaburzenia tarczycy, z czego u 20 \% pacjentów występuje wysoka niewydolność gruczołu skutkująca koniecznością przyjmowania leków utrzymujących prawidłową prace narządu. Dlatego też, pierwszą kontrolę hormonów tarczycy zaleca się wykonać 6 miesięcy po terapii, następnie regularnie raz na rok $[3,4,5,8]$.

\section{Zaburzenia metabolizmu węglowodanów i tłuszczy}

Ważne znaczenie w rozwoju insulinooporności i dyslipidemii ma kondycjonowanie w postaci napromieniania ciała techniką TBI. U 52 - 83 \% chorych można spotkać się z opornością organizmu na insulinę, a u 28 - 61 \% ze złym stężeniem lipidów i lipoprotein. Chorzy po leczeniu przygotowawczym narażeni są na rozwój cukrzycy 3,5 krotnie bardziej niż osoby nienapromieniane. Procedura TBI stanowi niezależny czynnik ryzyka rozwoju cukrzycy. U 8 \% pacjentów obserwuje się rozwój cukrzycy typu 2 [4].

\section{Zaburzenia wzrostu kości}

Zaburzenia ze strony układu szkieletowego powiązane są z liczbą przebytych frakcji napromieniania. Zastosowanie pojedynczej dawki wiąże się z większym ryzykiem rozwoju zaburzeń związanych ze wzrostem kośćca niż przy stosowaniu dawki wielokrotnej. Brauner i wsp. zauważyli gwałtowne obniżenie się tempa wzrastania po 3 latach od przeprowadzonej terapii jednofrakcyjnej wynoszącej 10 Gy. U drugiej grupy, u której zastosowano wielofrakcyjną radioterapię ( 6 x 2 Gy), poziom hormonu wzrostu był prawidłowy. Jednak po upływie 5 lat wystąpiło podobne zahamowanie szybkości wzrostu. Najczęściej powstałe uszkodzenia dotyczą kręgosłupa, w którym znajduje się obszar wzrostu kości, ale również mogą dotyczyć zniszczenia nasad kostnych w kościach i komórkach somatotropowych przysadki. Uszkodzenie obszaru podwzgórzowo - przysadkowego, powoduje ograniczenie wydzielania hormonu wzrostu (GH, ang. growth hormone), który jest bezpośrednią przyczyną powstania niedoboru hormonu co wpływa na wystąpienie niskorosłości w przyszłości. Dawka 60 Gy, powoduje martwicę kości i chrząstki, natomiast dawki poniżej 20 Gy wpływają na zahamowanie rozwoju kostniny $[2,3,4,5,6,8]$.

\section{Gonady}

Hipogonadyzm, który występuje prawie u wszystkich kobiet dojrzałych, po allogenicznym przeszczepie komórek krwiotwórczych, należy do najczęściej występujących powikłań popromiennych. U dziewcząt powoduje zahamowanie tylko części gonad, z intensywnym przebiegiem dojrzewania i z przyspieszonym wyciszeniem jajników. U płci żeńskiej, w pęcherzykach pierwotnych znajdują się owogonie, które są wysoce wrażliwe na radioterapię. Dawka w pęcherzykach pierwotnych nie może przekroczyć o,1 Gy. Ubytki w pęcherzykach, które spowodowane są napromienianiem, mogą mieć wpływ na poziom hormonów, co wiąże się z ryzykiem powstania zaburzeń cyklu płciowego. Dawki stosowane w procedurze TBI (powyżej 12 Gy) powodują zniszczenie wszystkich oocytów u dziewczyn powyżej 10 roku życia i eliminacje połowy oocytów u dziewczyn poniżej 10 roku życia. Frakcjonowanie dawki ma wpływ na powrót funkcji jajników. U mężczyzn komórki płciowe oraz jądra komórek Sertoliego występujące w nabłonku plemnikotwórczym są komórkami bardzo wrażliwymi na promieniowanie. Natomiast wysoko radiooporne są plemniki i spermatydy, które tolerują dawkę 15 Gy i większą. Trwała lub przejściowa niepłodność związana jest z przekroczeniem dawki w komórkach radioopornych. Przekroczenie dawki (5-6 Gy) powoduje ryzyko powstania trwałej niepłodności. Teoretycznie dzięki repopulacji nabłonka, możliwe jest przywrócenie płodności komórek, jednak potencjalnie mogą one posiadać wadę genetyczną $[2,3,8]$.

\section{Układ sercowo - naczyniowy}

Nowotwory występujące w młodym wieku bardzo często są przyczyną powstawania problemów sercowo - naczyniowych w późniejszym, dorosłym życiu. Zmiany związane z napromienianiem TBI mogą dotyczyć mięśnia sercowego, wsierdzia, układu przewodzenia oraz tętnic wieńcowych. W przyszłości mogą powodować 
zaburzenia ze strony funkcjonowania serca do których należy arytmia oraz kardiomopatia [6].

\section{Tkanki krwiotwórcze i krew}

Następstwem radioterapii zastosowanej przed przystąpieniem do przeszczepu komórek macierzystych może być zmniejszenie się elementów morfotycznych krwi spowodowanych uszkodzeniem szpiku kostnego. W wyniku napromieniania powstaje zespół szpikowy, który przybiera postać łagodną lub ostrą. Łagodną postać szpikową możemy zaobserwować przy podaniu dawki 2 - 4 Gy, natomiast ostra postać uaktywnia się po dawce 4-6 Gy. Napromienienie szpiku kostnego charakteryzuje się spadkiem kolejno krwinek białych, zwłaszcza limfocytów, granulocytów, trombocytów i erytrocytów. Dawki, które wpływają na zmniejszenie się o 50\% komórek krwi wynoszą dla płytek krwi 5,75 Gy, dla retikulocytów 1 Gy, dla granulocytów 1,5 Gy i limfocytów 0,4 Gy. Do objawów niepożądanych napromienienia szpiku kostnego należy gwałtowny spadek elementów morfotycznych, powstanie krwotoków, zaburzenie odporności. Całkowity zanik funkcji szpiku, może wiązać się z zaburzeniem krzepliwości krwi, zanikiem komórek odpornościowych, które odpowiadają za prawidłowe zwalczanie infekcji oraz ze spadkiem ilości granulocytów i komórek krwi [2].

\section{Układ oddechowy}

Podczas przeprowadzania procedury TBI płuca osłonięte zostają przez indywidualnie dopasowaną osłonę wytopioną ze stopu Wooda. Tkanka płuca jest szczególnie wrażliwa na działanie cytostatyków i radioterapię więc zespół interdyscyplinarny, składający się z lekarza radioterapeuty, fizyka medycznego oraz elektroradiologa pracuje nad ograniczeniem dawki w tym obszarze. W Wielkopolskim Centrum Onkologii przy wykonywaniu napromieniania techniką TBI dawka na płuca nie może przekroczyć 9 Gy. Według zaleceń QUANTEC (ang. Quantitative Analysis of Normal Tissue Effects in the Clinic) przy dawce $7 \mathrm{~Gy}$, zaabsorbowanej w płucach (traktowany jako cały narząd) prawdopodobieństwo wystąpienia zapalenia płuc wynosi $5 \%$ [2]. Z badań przeprowadzonych przez Springermeyera i in. u 20 \% biorców szpiku kostnego, pomimo ich długiego przeżycia, pojawiły się zmiany w postaci zaburzeń wentylacyjnych ze strony układu oddechowego takich jak zmniejszenie całkowitej pojemności płuc (TLC, ang. Total lung capacity) czy zmniejszenie pojemności życiowej (VC, ang. Vital capacity) [8]. Wielkość powikłań w dużym stopniu zależy od wielkości dawki pochłoniętej oraz od sposobu i szybkości frakcjonowania. Popromienne objawy ze strony płuc można podzielić na powikłania ostre i przewlekłe. Najczęstszym powikłaniem ze strony układu oddechowego, po radioterapii całego ciała jest śródmiąższowe zapalenie płuc. Zaburzenie pojawia się w okresie 120 dni z częstością 5 - 20 \%. Cechuje go zmiana w obrazie rentgenograficznym klatki piersiowej oraz pojawiające się symptomy takie jak zaburzenie oddychania, gorączka lub jej brak, zmniejszona ilość tlenu we krwi oraz kaszel nadproduktywny. Samoistnie lub w wyniku przewlekłego zapalenia płuc może dojść do zwłóknienia tkanki płucnej. Najczęściej pojawia się po 5 latach od zakończonej radioterapii, a po 15 20 latach dotyczy 3,5 \% pacjentów. Choroba pęcherzyków płucnych najczęściej przebiega bezobjawowo. Jeśli jednak pojawią się symptomy to związane są one z dusznością, nawracającym zapaleniem płuc, zapaleniem opłucnej, zmniejszeniem wydolności oddechowej [6]. Diagnostyka rutynowo przeprowadzana u chorych po przeszczepie szpiku kostnego opiera się na zdjęciu klatki piersiowej, badaniu przepływ - objętość oraz badaniu spirometrycznym [7].

\section{Narząd wzroku}

Soczewka oka należy do najbardziej wrażliwych na promieniowanie jonizujące narządów. Odczyn popromienny w soczewce w postaci zaćmy tylnej podtorebkowej jest typowym działaniem deterministycznym promieniowania jonizującego. Dawka, powyżej której możliwy jest rozwój zaćmy wynosi 4 Gy. Przy przekroczeniu dawki progowej prawdopodobieństwo wystąpienia odczynu popromiennego wzrasta wraz z wysokością dawki (zależność dawka - efekt). Powyżej dawki 12 Gy możliwość zmętnienia soczewki wynosi blisko $100 \%$. Według badań przeprowadzonych w Seattle u chorych napromienianych frakcjonowanym FTBI (ang. Fractioned Total Body Irradiation) ryzyko wystąpienia powikłań popromiennych ze strony soczewki wynosi 18 \%. Ryzyko może wzrosnąć aż do 80\% u pacjentów u których wykonano jednorazowe 
napromienieniem całego ciała $[1,2,6]$.

\section{Układ moczowy}

Powikłania popromienne ze strony układu moczowego mogą objawiać się występowaniem wysokiego poziomu kreatyniny i mocznika we krwi, obrazem niedokrwistości oraz w skrajnych przypadkach niewydolnością nerek. Pierwsze dane dotyczące powstania przewlekłej choroby nerek po przeszczepie komórek macierzystych odnotowano w 1978 r. Zwiększone, popromienne zapalenie nerek może wystąpić 6 12 miesięcy od przeszczepu szpiku kostnego i związane jest przede wszystkim z zastosowaniem radioterapii całego ciała oraz z wieloośrodkowym leczeniem chemioterapeutycznym $[6,8]$.

\section{Nowotwory wtórne}

U części chorych, wiele lat po zakończonej terapii następuje nawrót nowotworu. Po upływie 5 latach od przeszczepu obserwuje się wzrost zachorowalności o 1,7 \% . Po upływie 15 lat ryzyko wzrasta do 13,5 \%. Do grupy najczęściej występujących nowotworów wtórnych należą białaczki, zespół mielodysplastyczny (MDS) oraz guzy lite lub raki wywodzące się z tarczycy, kości, wątroby, ośrodkowego układu nerwowego oraz skóry [6].

Ze względu na występowanie wielu powikłań popromiennych ze strony narządów zaleca się prócz kontroli hormonów tarczycowych, kontrole masy ciała, wykonywanie morfologii krwi, układu homeostazy, stężenia kreatyniny oraz bilirubiny, pomiaru elektrolitów i aktywności aminotransferaz w surowicy krwi $[6,8]$.

\section{Podsumowanie}

Podstawowym zadaniem radioterapii jest jak najdokładniejsze dostarczenie dawki w obszar guza przy jednoczesnej, maksymalnej ochronie narządów prawidłowych. Podczas wykonywania procedury TBI napromieniane jest całe ciało pacjenta. Dlatego też narządy takie jak jama ustna, mózg, soczewka oka, serce, wątroba, nerki, pęcherz moczowy, jelita oraz męskie i żeńskie narządy płciowe objęte zostają wysoką dawką terapeutyczną. Jedynie płuca przy napromienianiu pól przednio - tylnych i tylno - przednich zabezpieczone są przed przez osłonę wytopioną ze stopu Wooda. Rozwój nowych technik radioterapii takich jak VMAT (ang. Volumetric Arc Therapy) czy tomoterapia, umożliwia większą ochronę narządów krytycznych, a zarazem pozwala otrzymać lepsze rozkłady dawek w obszarze tarczowym. Obie metody znalazły zastosowanie w leczeniu chorych z rozrostowymi nowotworami układu krwiotwórczego. Układ listków MLC (ang. Multi Leaf Colimator) wbudowany w aparat daje możliwość dokładnego dopasowania się do kształtu zmiany. Skrócenie czasu leczenia oraz przygotowania pacjenta na aparacie stanowi kolejną zaletę technik. Pacjenci leczeni są w jednej pozycji (na plecach), która w przeciwieństwie do pozycji leżenia przy wykonywaniu procedury TBI (pozycja na plecach, na brzuchu, na boku) zapewnia powtarzalność oraz dokładność ułożenia, co ma znaczenie dla komfortu leczenia. Perspektywa wykorzystania nowych technik radioterapeutycznych u pacjentów przygotowujących się do przeszczepu szpiku kostnego daje szanse maksymalnego zaoszczędzenia narządów prawidłowych, co może mieć istotny wpływ na zmniejszenie się odsetka powikłań popromiennych, a zarazem skutkować wzrostem krzywej przeżycia pacjentów.

\section{Konflikt interesu / Conflict of interest}

Nie występuje.

\section{Etyka / Ethics}

Treści przedstawione w artykule są zgodne z zasadami Deklaracji Helsińskiej, dyrektywami EU oraz ujednoliconymi wymaganiami dla czasopism biomedycznych. 


\section{Piśmiennictwo / References}

[1] Czajkowski P. Aspekty fizyko - medyczne w napromienianiu całego ciała (TBI). Inżynier i Fizyk Medyczny 2015;4(1): $45-53$.

[2] Konstanty E. Opracowanie i weryfikacja metody napromieniania całego ciała/szpiku akceleratorem tomoterapii spiralnej. Praca doktorska, Poznań 2013.

[3] Zaucha E. Czynniki ryzyka wczesnych i późnych powikłań po transplantacji autologicznych komórek krwiotwórczych u chorych na zaawansowane nowotwory. Rozprawa habilitacyjna. Gdańsk 2008.

[4] Wędrychowicz A, Zygmunt - Górska A, Wojtyś J. Powikłania endokrynologiczne po allogenicznym przeszczepie komórek krwiotwórczych w okresie rozwojowym - prezentacja przypadku i omówienie metody. Endokrynologia pediatryczna 2012;3(40):67 - 80.

[5] Iwankiewicz J, Kałwak K, Wójcik D, Barg E. Zaburzenia wzrastania u dzieci po przeszczepieniu komórek krwiotwórczych - problem diagnostyczny i terapeutyczny. Acta Haematologica Polonica 2004;3(35):329 $-341$.

[6] Krawczuk - Rybak M. Odległe następstwa leczenia przeciwnowotworowego w dzieciństwie - na podstawie przeglądu i doświadczeń własnych. Developmental Period Medicine 2013;2 (XVII): 130 - 136.

[7] Willa - Janc E, Wójcik I, Gorczyńska E, Turkiewicz D. Badania czynnościowe płuc po przeszczepie szpiku kostnego - doświadczenia własne. Alergia Astma Immunologia 2006;11(3): 162 - 167.

[8] Leiper A. Late effects of total body irradiation. Arch Dis Child 1995;72(5):382-5

[9] Głowacki G, Miszczyk L, Slosarek K, Jochymek B, Woźniak G, Matulewicz Ł, Radwan M, Leszczyńska P, Dolla Ł, Najda J, Krużel T, Czerw T, Saduś - Wojciechowska M, Giebel S. Napromienienia szpiku całego ciała - prezentacja metody. NOWOTWORY Journal of Oncology 2014; 4(64):314 - 320. 